\title{
Worship, Reflection, Empirical Research
}

My Mao Zedong Trilogy

\section{Ding Dong}

Translator. Stacy Mosher

\section{(2) OpenEdition}

\section{Journals}

\section{Electronic version}

URL: http://journals.openedition.org/chinaperspectives/5875

DOI: 10.4000/chinaperspectives.5875

ISSN: 1996-4617

\section{Publisher}

Centre d'étude français sur la Chine contemporaine

\section{Printed version}

Date of publication: 4 June 2012

Number of pages: 55-59

ISSN: 2070-3449

\section{Electronic reference}

Ding Dong, «Worship, Reflection, Empirical Research », China Perspectives [Online], 2012/2 | 2012,

Online since 30 June 2015, connection on 28 October 2019. URL : http://journals.openedition.org/ chinaperspectives/5875; DOI : 10.4000/chinaperspectives.5875 


\title{
Worship, Reflection, Empirical
}

\section{Research: My Mao Zedong Trilogy}

\author{
DING DONG
}

\begin{abstract}
In my youth, I was a worshipper of Mao Zedong. From the latter stage of the Mao Era to the early years of Reform and Opening, I began to reflect on Mao and the Communist Revolution he launched. In recent years I've devoted myself to empirical historical research on Mao, seeking the truth about Mao and China's modern history.
\end{abstract}

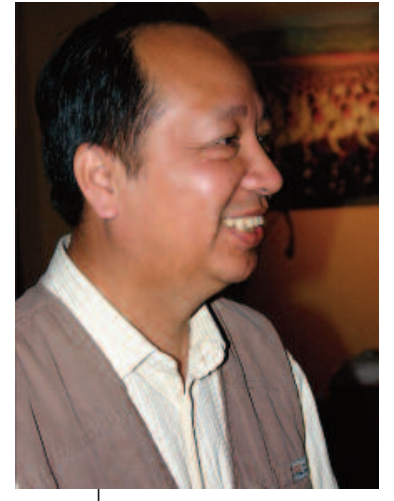

Ding Dong in Beijing in 2012. () Ding Dong

\section{The stage of worship}

was born in 1951 and came of age in the Mao Zedong Era. Mao worship was not a mental phenomenon unique to me, but was common to all in my generation. From primary to secondary school, the education I received and the discourse that influenced me were bathed in the halo of Mao's glamour. I was surrounded by news and artistic messages crafted according to Mao's value system. In the classroom, correct answers were determined by Mao's views. Mao was on a higher plane than parents and teachers. The cumulative effect of all of this made its mark on the impressionable youth that I was.

I turned 15 the year that the Cultural Revolution began. Propaganda devoted to Mao as an individual intensified. If it is said that Mao and the Communist Party were equally sacred prior to the Cultural Revolution, Mao gained pre-eminence over the Communist Party once the Cultural Revolution began. As internal Party struggles became more acute, the Party's top leaders and major portions of the leadership ranks at every level became targets of revolutionary struggle as factions of counterrevolutionary revisionists and capitalist roaders. Young people have asked me, How did you feel at the time? I respond truthfully, When the Cultural Revolution began, I was galvanised. A 15-year-old high school student was suddenly liberated from the classroom and spent his days reading all kinds of big character posters exposing problems with the leadership that no one had ever heard of before. It genuinely aroused heartfelt admiration for Mao's prescience in ferreting out China's revisionist peril. Although my family did not belong to any of the Five Red Categories, ${ }^{(1)}$ and I was soon cut down to size in the great revolutionary tide, my heart remained devoted to Mao and the path of idealism along which he directed us. I hiked from Guangzhou to Jiangxi's Jinggang Mountains (2) during the Cultural Revolution's Great Link-up Campaign, (3) and while working in a production brigade in the countryside, I hiked from Beijing to Shanxi's Qin County. This should be considered a response to the revolutionary fervour Chairman Mao kindled in me; however difficult or tiring, it seemed bold and heroic. Our generation modelled its actions on stories of the Red Army's Long March heard since childhood.

At that time, propaganda proclaimed the three historical milestones of Marxism as Marx's founding of scientific socialism, Lenin's construction of a socialist state, and Mao Zedong's solution to the restoration of capitalism once the proletariat seized power. This theory, known as sustained revolution under proletarian dictatorship, was at that time enthralling and a source of pride for all Chinese, and I likewise accepted it without reservation. After 1969, when I was transformed from Beijing high school student to rusticated intellectual youth, the harsh reality of my living conditions began to challenge the internal consistency of my world view. At that time, all levels of the government regularly convened assemblies to "integrate learning and practical application" of Mao Zedong Thought ${ }^{(4)}$ as a means of promoting day-to-day work. But I was put off by the exaggeration and hypocrisy of the speeches. I recall a model opera at that time called "Taking Tiger Mountain by Strategy," which included a line that became popular doggerel: "What kind of horse is it? A horse whose rump is patted. What kind of knife is it? A knife stabbed in another's back." This summarised the political atmosphere of that time. For that reason, in the latter stage of my time in the production brigade, my propensity for frank talk caused friction with local cadres, and I barely escaped being arrested and made into an example.

The "September 13 Incident" of $1971^{(5)}$ smashed the foundation of Mao's personality cult. In the public's mind, Lin Biao was the ultimate disciple and standard-bearer of Mao Zedong Thought, as well as Mao's closest comradein-arms and successor, but he had attempted to flee China. The myth of the

1. Translator's note (hereafter TN): I.e., families with backgrounds as workers, poor and lower peasants, revolutionary cadres, or revolutionary martyrs, as opposed to the "black categories" of landlords, rich peasants, counterrevolutionaries, criminals, and capitalists.

2. TN: Renowned as the birthplace of the Red Army and the "cradle of the Chinese revolution."

3. TN: The "Chuan Lian" movement, translated variously as "linked up," "joining the great circuit," "the great exchange," etc., was a campaign during which youths travelled across the country on foot, in trains, and on buses to establish ties with one another and offer mutual support in the revolutionary experience.

4. Author's note (unless otherwise specified, all notes hereafter are author's notes): Lin Biao proposed that in studying Chairman Mao's works it was necessary to "bring questions, apply learning to practical life, integrate learning and doing, start with the knowledge most urgently needed, and get instant results."

5. On 13 September 1971, Lin Biao, his wife Ye Qun, son Lin Liguo, and others attempted to escape China by air. Their plane crashed near Ondorhaan, Mongolia, and all aboard were killed. 
all-prescient Mao was no longer sustainable. Propaganda for the Peak Theory - that Mao Zedong Thought represented the highest plane of Marxism inevitably waned. I likewise encountered and sought out philosophical and cultural alternatives to Mao. By the latter stage of the Cultural Revolution, what I was avidly reading was no longer the regime's mainstream propaganda, but rather the gray and yellow-covered books ${ }^{(6)}$ of the pre-Cultural Revolution era, as well as publications circulated internally during the Cultural Revolution. Books such as The Memoirs of Nikita Khrushchev and Milovan Djilas's The New Class: An Analysis of the Communist System had an enormous impact on my thinking.

Social reality also made me aware of how the targets of Mao's sustained revolution diverged from actual public sentiment. The cadres attacked and purged in the latter stages of the Cultural Revolution, in campaigns such as those to criticise Lin Biao and Confucius and to "criticise Deng Xiaoping and the Right-Deviationist Wind of Reversing Verdicts," were not necessarily those who had aroused the greatest popular antipathy. Nor did the officials who had most harmed the interests of the masses seem to be the targets of these movements. The revolution Mao mobilised no longer coincided to any significant degree with the sources of real popular discontent. Furthermore, too many of those who answered Mao's call to charge the enemy lines in repeated political campaigns also became sacrificial victims. By the time Mao died, his glorious aura had already substantially diminished in my mind.

\section{The stage of reflection}

Beginning with the latter stage of the Mao era, I experienced many political movements, and my attempts to preserve my own viewpoint inevitably caused me grief. After the Gang of Four was smashed, the purge of Gang associates in Shanxi led to the rise of one faction to purge another. At that time, I was working in the investigation and research office of the Shanxi provincial Party committee. The office, headed by Wu Xiang, (7) became a prime target for purging after being labelled a "Petöfi Club" (8) by provincial Party secretary Wang Qian, who was backed by Chen Yonggui. (9) During this purge, I personally experienced the ruthlessness, mercilessness, and utter irrationality of internal Party struggle, and the perversity of the official mindset. Although I narrowly escaped a second demotion to menial labour by taking the autumn 1977 college entrance examination, this encounter impelled me toward further reflection.

After beginning my studies at Shanxi University in spring 1978, I naturally became a sympathiser with Beijing's Democracy Wall and university student elections. I also became involved with several student publications at the university. The emancipated thinking of the top leadership at that time did not last long; in spring 1979, Deng Xiaoping gave his speech insisting on the Four Cardinal Principles ${ }^{(10)}$ and arrested Wei Jingsheng, ${ }^{(11)}$ signifying the end of the brief honeymoon Deng had enjoyed with China's intelligentsia and those outside the system who were calling for democracy and freedom. This was the end of the ascendency China's intellectuals had enjoyed, and they entered an era of political chess between left and right. My thinking and sentiment consistently inclined toward what officialdom regarded as bourgeois liberalisation, even more so after I abandoned politics for scholarly pursuits in the mid-1980s. My reflections on Mao also unfolded along several directions. After the 1989 June 4th Incident, this process gained depth.

I first began to reflect on the repeated political campaigns led by the CCP, not merely after but already before the founding of the PRC. Many facts not previously encountered or understood were first broached in scar literature ${ }^{(12)}$ and reflection literature, after which I read memoirs of the people involved and treatises by researchers, which made me see the ruthless aspect of Mao's revolution and the CCP's history.

My second line of reflection focused on the International Communist Movement, which revealed to me the bloodbath behind the scenes, from the Soviet Union to Eastern Europe, and from Stalin to Lenin. By choosing the road from Lenin to Stalin, Mao did not take the right path toward human civilisation, but rather veered off on the wrong path toward Utopia. The ideological framework of the Five Stage Theory of history and historical materialism established from Marx to Stalin to Mao was a subjective fabrication. From Stalin to Mao, this thought system became policy; in domestic politics people were branded as enemies, and some designated as landlords, rich peasants, or capitalists were stripped of their economic assets and physically exterminated, inflicting grievous internal injury on Chinese society. The changes brought about by China's implementation of market economics exposed the failure of the socialist experiment established on the foundation of Marx's surplus value doctrine, which negated the market and capitalism and abolished exploitation. Mao's "May 7 Road" (13) was not a

6. In the 1960s, a series of books were published in China under restricted circulation, their back covers stamped with the words "for internal reference." These were meant as reference materials for the senior leadership and academic theorists to criticise revisionism. Among them, books of political theory had gray covers, and were referred to as "gray-covered books," while literary works had yellow covers and were referred to as "yellow-covered books."

7. Wu Xiang, born in 1921, was a native of Anhui who served as deputy Party secretary and director of the policy survey and research room of the Shanxi provincial Party committee, as well as deputy director of the State Council's Rural Development Research Centre and other posts.

8. Named after the revolutionary poet Sandor Petöfi, Hungary's Petöfi Club was established in 1954 as a cultural organisation under the leadership of the Hungarian Workers Youth League. It became more active in 1956 and sponsored a series of seminars on ideological emancipation, discussing economics, philosophy, history, news media, and other such issues, eventually influencing Hungary's political progress. It was stamped out during the Soviet suppression of the 1956 Hungarian Uprising.

9. Chen Yonggui (14 February 1915 - 26 March 1986) served at one point as branch Party secretary of Dazhai, Shanxi Province. In 1973 he was elected to the standing committee of the CCP Central Committee Politburo, and in 1975 he served as vice-premier of the State Council of the PRC. He resigned in 1980.

10. During a Party conference to discuss ideological guidelines on 30 March 1979, Deng Xiaoping proposed maintaining the socialist road, the dictatorship of the proletariat (i.e., the people's democratic dictatorship), the leadership of the Communist Party, and Marxist-Leninist-Mao Zedong Thought as the "four cardinal principles."

11. Wei lingsheng was a worker in Beijing who posted on the Xidan Democracy Wall an essay proposing political democratisation as the fifth modernisation, and warning of the possibility of Deng Xiaoping becoming a new dictator. The CCP leadership sentenced him to 14 years in prison.

12. Scar literature is a literary trend that started in mainland China at the end of the 1970s. It focused on showing the harm inflicted on the Chinese people by the Cultural Revolution and other political movements. The trend's name derived from a short story by the Shanghai writer Lu Xinhua entitled "Scar."

13. On 7 May 1966, Mao Zedong wrote the following letter to Lin Biao:

Comrade Lin Biao: I received the general logistics department report that you sent on 6 May, and I feel this plan is very good. Would it be possible to distribute this report to all military regions and ask them to convene meetings of corps-and division-level cadres to discuss it, and report their views to the Military Commission? Then the report can be approved by the Central Committee, followed by appropriate directives to the entire military establishment. Please decide on this. As long as there is no world war, the army should be a big university; even if there is a Third World War, it's quite possible for it to become this kind of big university, in which all kinds of work can be done apart from fighting. Isn't that what we did in all of the anti-Japanese base areas during the eight years of the Second World War? In this big university, people can study politics, military affairs, and culture. They can also engage in agricultural sideline production. They could also operate some small to medium-sized factories to manufacture certain products they need as well as items that can be provided to the state in an equal value exchange. They can also undertake mass work and take part in the socialist education movement's "four clean-ups" campaign in the factories and villages. When the socialist education movement is finished, there is always other mass work to be done to ensure that the military and the people remain integrated. They should also regularly participate in Cultural Revolution struggles criticising the bourgeoisie. In this way, military training, war agriculture, war industry, and soldier-civilian unity can be combined. But this requires appropriate deployment, with one unit engaging in only one or two of the mass, agricultural, industrial, or civilian activities, not all at the same time. In this way, an army of several million can be enormously effective. 
blueprint for the society of the future, but rather a mutation of agricultural socialism.

My third reflection was on China's history, from the First Emperor Qin Shihuang to Liu Bang, Zhu Yuanzhang, and Hong Xiuquan; (14) it revealed Mao's connection to China's tradition of imperial rule and peasant rebellion, and revealed to me Mao's cultural origins.

During the Mao era, propaganda declared that two-thirds of the world's people lived in an abyss of misery, and that the people of China were the most fortunate. It was only after my generation had the opportunity to understand the situation outside of China that this illusion was dramatically dispelled. The demonised Euro-American nations were not only materially prosperous and economically flourishing, but were also endowed with advanced science and education and generous social welfare systems. In particular, their system of democratic constitutionalism, which controlled the power of officials and restrained privilege and corruption, bestowed on their citizens a life of dignity. From the end of the Second World War until the early 1950s, Japan, Korea, and other Asian nations, along with the Taiwan region, had similar or even inferior living standards to that of mainland China. By the time of Mao's death, however, Japan and the Four Little Dragons of Asia had soared economically to join the ranks of the developed world. This contrast was not a historical inevitability, but rather resulted from the Mao's erroneous choices.

As a result of my reflections, I chose to bid farewell to Mao Zedong and to rejoin mainstream human civilisation and universal values.

\section{Empirical research}

Since entering the new millennium, the best interests of the Chinese people have diversified, as have their values, and views of Mao Zedong are also undergoing a diversification process. There is no longer a consensus on Mao in China, with a very broad spectrum existing between wholesale endorsement and thorough negation.

Those who endorse Mao include old Leftists, who maintain a wholesale allegiance to the Leninist-Stalinist-Maoist system and to the ideology of Mao's last years. They believe that China's current system is one of revisionism and restoration of capitalism, and that the proper path would be to negate Deng Xiaoping, with some even advocating a reversal of the verdicts against Jiang Qing and Zhang Chunqiao. ${ }^{(15)}$ Supporters also include grassroots factions with populist tendencies, who believe that Mao represents egalitarianism, the workers and peasants, and the poor. They use Mao as their rallying point in calling for another revolution to punish official corruption, wipe out the wealthy, and aid the indigent. Another portion consists of former members of the Cultural Revolution's rebel faction, whose ideological and sentimental reference is the early years of the Cultural Revolution, and who recall with nostalgia the brief honeymoon period of Mao and the rebel faction. All of these viewpoints can be easily found represented on websites such as Utopia. ${ }^{(16)}$ There is also a portion made up of statists fixated on opposing imperialism and Western hegemony. They applaud Mao's daring to stand up to the Great Powers and battle hegemonism and his refusal to "hide one's strength and bide one's time" (tao guang yang hui), but fall short of a wholesale endorsement of Mao's domestic agenda. These various Maoist factions are not genuine fundamentalists; most pick and choose the ideological aspects that suit their practical needs. It is evident, however, from more than 10,000 postings on the Internet against criticism of Mao by scholar Mao Yushi that this ideological trend has a definite mass foundation and substantial social capacity.

The mainstream authorities, well aware that Mao is the progenitor of the Chinese Communist Party and of the People's Republic of China, and is therefore both China's Lenin and its Stalin, are prevented from casting aside Mao's banner lest both Party and nation lose their legitimacy. Deng Xiaoping dissected Mao's banner and the errors of Mao's last years in the form of the "Resolution Regarding Certain Historical Issues since the Founding of the PRC." (17) Today's leaders continue to maintain this stand. Recently, numerous images of Mao, Deng, Jiang Zemin, and Hu Jintao were shipped to Tibet in order to counter the influence of the Dalai Lama. (18) The "red song" campaign in Chongqing not so long ago was also an attempt to cash in on Mao's political capital. (19) Even so, the leadership's endorsement of Mao is a matter of pragmatism. Mao-era economic and social policies cannot benefit the current leadership and have therefore been revised or abandoned.

Opposition to Mao likewise has different aspects and levels. Some opponents date their negation to the Cultural Revolution, and others to the CCP's Eighth Party Congress. ${ }^{(20)}$ Some reject Mao but endorse the Communist-led revolution. Some reject Stalin but endorse Lenin. Some reject Lenin but preserve Marx. Some feel that the entire Communist Movement was a wrong turn in the history of civilisation. For example, Zhu Houze, who at one time served as head of the CCP Central Committee Propaganda Department, carried out a comparison of four political thought trends with worldwide influence and negated Leninism and Fascism. (21)

Likewise with workers, they are mainly engaged in industry, but at the same time they should also take part in military affairs, politics, and culture as well as the "four clean-ups," and in criticising the bourgeoisie. Where conditions allow, they should also engage in agricultural sideline production, for example in the Daqing oil fields.

Peasants engage mainly in agriculture (including forestry, herding, sideline production, and fisheries), but should also learn military affairs, politics, culture, and where conditions allow also participate in setting up collective small factories, as well as criticising the bourgeoisie.

It's the same for students, who mainly study, but at the same time learn non-academic subjects such as industry, agriculture, and military affairs, while also criticising the bourgeoisie. The educational system must be reduced; education must be revolutionised. The phenomenon of bourgeois intellectuals dominating our schools cannot continue.

Commerce, service industries, and staff of the administrative units of the Party and government must do likewise, conditions allowing.

There is nothing new or creative in any of the above; many people have been doing this for years already, it just hasn't become universal. As for the army, it has already been doing this for decades, but now it's time to develop it further.

This letter subsequently came to be referred to as the "May 7 Directive." The practice of people in different trades learning each others' occupations and for cadres, students, and intellectuals to go down to the countryside for agricultural service became known as the "May 7 Road."

14. Liu Bang was the founding emperor of the Han Dynasty; Zhu Yuanzhang was the founding emperor of the Ming dynasty; Hong Xiuquan was the leader of the Taiping Rebellion. All are considered representative of peasant rebellions in China's history.

15. TN: Zhang Chunqiao (1917-2005) was a political theorist and member of the Gang of Four.

16. TN: Wuyou zhi xiang, www.wyzxsx.com. The website became disabled around the time of the Bo Xilai scandal in Chongqing in April 2012.

17. "Resolution Regarding Certain Historical Issues since the Founding of the PRC" (passed unanimously during the sixth plenum of the CCP's Eleventh Central Committee on 27 June, 1981), http://www.cctv.com/special/733/-1/47008.html (consulted on 19 April 2012).

18. The unveiling of leader portraits and flag-raising ceremony by the Tibet Autonomous Region Party committee and government was attended by TAR Party secretary Chen Quanguo. See Tibet Daily, 24 January 2012.

19. TN:The campaign was launched by Chongqing Party secretary Bo Xilai in 2011 to mark the 90th anniversary of the founding of the Chinese Communist Party. See Barbara Demick, "'Red song' campaign in China strikes some false notes," Los Angeles Times, 3 June 2011, http://articles.latimes.com/2011/jun/03/world/la-fg-china-red-20110604 (consulted on 19 April 2012).

20. TN: The disastrous Great Leap Forward was launched in December 1957 during the Eighth Party Congress, which was the first Congress following the founding of the PRC.

21. Zhu Houze, "Dangjin wenhua jiaolü wenti" (The current problem of cultural anxiety), Yanhuang Chunqiu, no. 10, 2010. 
My own inclination is to employ empirical research to restore Mao's true historical features. Given the fact that high-level archives remain confidential, this is very difficult work that can only be performed slowly and patiently. There is no essential conflict between empirical research and reflection. Empirical research, however, is characterised by a sober and objective attempt to clarify the truth, rather than a self-referential expression of personal feelings.

For example, one question worthy of empirical research is whether Mao had a Party-based or family-based conception of succession of power. Partybased succession, maintaining one-party dictatorship, presupposes Party rule of the nation, with succession decided within the Party leadership rather than passed to a member of Mao's family. Up until the collapse of the Soviet and Eastern European regimes in the late 1980s and early 1990s, most countries in the International Communist Movement implemented this kind of system. Under family-based succession, the highest authority is passed to an offspring, sibling, or spouse. A minority of countries in the International Communist Movement have implemented this kind of system. For example, in North Korea, rule has passed through three generations from Kim Il-sung to Kim Jong-il to Kim Jong-un, with no compunction against implementing a so-called "Communist hereditary system." In Cuba, Fidel Castro was succeeded by his younger brother Raul. Romania's Nicolae Ceausescu served as party leader and head of state, while his wife Elena served as second-incommand of the party, and his son Nicu served as first general secretary of the Communist Youth League, in preparation for family-based succession. This plan was brought to ruin, however, with the overthrow of the Ceausescu regime in 1989.

In China's recorded history, the ancient dynasties all implemented family-based succession. In 1912, the Qing emperor abdicated, and the Republic of China was born, its president elected by ballot. The first president, Yuan Shikai, in his later years restored the monarchy, intending succession to be handed to his son, but abandoned his plan upon encountering intense popular opposition. Chiang Kai-shek's wielding of state power in Taiwan was passed to his son, Chiang Ching-kuo. In his later years, however, Chiang Ching-kuo abolished martial law and lifted the ban against opposition parties, ending the claims of the Chiang dynasty. In the present world, some democratic countries still maintain hereditary kingship. Because they implement constitutional monarchy, however, kingship has acquired a ceremonial status that does not confer ultimate power over the country; actual national authority is held by parliament and government, which are elected by popular ballot. This does not constitute family-based rule. Whether Mao's actual intention was for Party-based succession or family-based succession remains a topic of controversy in China's scholarly community.

A few years ago, the scholar Xin Ziling published a book entitled The Setting of the Red Sun: Mao's Lasting Merits and Demerits, ${ }^{(22)}$ which held that Mao intended for his wife Jiang Qing to succeed him in ruling China, and which gave credence to rumours that Mao had produced and left behind name lists of cabinet officials. Xin believes that Mao's intention upon his death was that Jiang Qing should become Party chairman, or that Jiang should assist Mao Yuanxin's "ascent to the throne." (23) Since such authoritative figures as Li Rui and Xie Tao (24) wrote forewords to the book, it has been highly influential. Up to the present, many scholars believe that Mao intended to hand his power to Jiang Qing.

If Mao did intend to arrange for Jiang Qing or Mao Yuanxin to succeed him, this would of course qualify as family-based succession. The tenability of this claim must nevertheless be judged by fact rather than through emo- tion. Yan Changgui and Yang Yinlu published an article in Yanhuang Chunqiu (25) laying out testimony they obtained from Mao Yuanxin, Zhang Yufeng, (26) and others. I feel their article is credible, while the various rumoured cabinet lists in which Mao named Jiang Qing Party chairman are not credible.

Based on publicly accessible historical materials, it is a fact that Mao groomed his son, Mao Anying, as his successor. At Yan'an, he had Mao Anying emulate the model farmer Wu Manyou, and also had Kang Sheng, Tian Jiaying, Zeng Yanxiu, (27) and others teach his son about China's history and culture and take him to participate in land reform. After the establishment of the PRC, Mao had Mao Anying serve in a leadership capacity at a Beijing factory, and also sent him with Peng Dehuai (28) to fight for North Korea. All this can be regarded as Mao providing his son with comprehensive political training. This plan was terminated, however, when the younger Mao was killed in the Korean War. Mao Zedong exclaimed, "Is the creator of bad precedent to be left without posterity?" (29)

Subsequently, although others in Mao's family, including Jiang Qing, Mao Yuanxin, and $\mathrm{Li} \mathrm{Na}$, ${ }^{(30)}$ were appointed to relatively important positions, there is no irrefutable evidence that Mao wanted them to succeed him. From the Ninth Party Congress until 1976, others repeatedly proposed that Jiang Qing be made a member of the Politburo Standing Committee, but Mao consistently refused. Neither did Mao put Jiang in charge of any concrete operations. Mao knew that Jiang had many enemies and that she would be unable to maintain control of the central government. For that reason, up until his death he never gave her any opportunity to manage daily operations in the central government. Mao Yuanxin had very strong administrative abilities; Mao Zedong treated him like a son, and during the Cultural Revolution, Zhou Enlai repeatedly arranged for the younger Mao to be put to good use in important postings. Just before the Ninth National

22. Xin Ziling, Hong taiyang de yunluo: qian qiu gongzui Mao Zedong (The setting of the red sun: Mao's lasting merits and demerits), Hong Kong, Shu zuofang chubanshe, 2007.

23. Mao Yuanxin, born in 1941, was the son of Mao Zedong's younger brother Mao Zemin. During the Cultural Revolution he served as vice-chairman of the Liaoning Provincial Revolutionary Committee, Party secretary of the Liaoning provincial Party committee, and political commissar of the Shenyang Military Region. From the end of 1975 to 1976 he served as liaison between Mao Zedong and the Central Committee Politburo. He was arrested in October 1976 and subsequently sentenced to 17 years in prison. He was released on medical parole in 1989, and completed his sentence in 1993, after which he worked as an engineering technician in Shanghai. He is now retired.

24. TN: Li Rui (1917- ) served as Mao's personal secretary in the 1950s. Xie Tao (1922-2010) was a veteran Party member and scholar.

25. Yan Changgui, Yang Yinlu, "Yi ze lishi chuanwen de zhen wei" (Fact and fiction behind a historical rumour), Yanhuang Chunqiu, no. 3, 2010

26. Zhang Yufeng, born in 1944, a native of Heilongjiang, served as Mao Zedong's confidential and personal secretary from 1970 onward.

27. Kang Sheng (1898 - 16 December 1975), a native of Jiao County, Shandong Province, served as vice-chairman of the CCP Central Committee and as vice-chairman of the standing committee of the National People's Congress. His Party membership was rescinded after his death. Tian Jiaying (1922 - 1966), a native of Chengdu, Sichuan Province, served as vice-director of the CCP Central Committee Political Research Room and of the CCP Central Committee General Office. He committed suicide at the outset of the Cultural Revolution. Zeng Yanxiu, a native of Yibin, Sichuan Province, born in 1919, served as publisher and chief editor of the People's Publishing House.

28. Peng Dehuai (1898 - 1974), a native of Xiangtan, Hunan Province, was Marshall of the PRC. He served as the PRC's Defence Minister and as commander-in-chief of the Chinese People's Volunteer Army.

29. At the Lushan Conference on 23 July 1959, Mao said, "The creator of bad precedent is left with no posterity. Have I no posterity? According to Chinese custom, only male offspring count as posterity, not female offspring. My one son was killed and another went mad, so I consider myself to have no posterity."

30. Li Na, born in 1940, was the daughter of Mao and Jiang Qing. At the outset of the Cultural Revolution she served as head of the editorial guidance committee of PLA Daily, and from 1974 to 1975 she served first as secretary of the Pinggu county Party committee and deputy secretary of the Beijing municipal Party committee. 
Party Congress, Mao Zedong gave instruction that neither Mao Yuanxin nor Li Na was suitable to serve as a delegate. ${ }^{\left({ }^{11}\right)}$ Likewise during the Tenth Party Congress Mao didn't allow Yuanxin to join the Central Committee. If Mao had intended for him to be his successor, he would not have blocked Yuanxin from joining the Central Committee. Up to the present, therefore, none of the publicly accessible reliable historical documentation provides sufficient proof that Mao planned for family-based succession.

Whether in his selection of Liu Shaoqi, Lin Biao, Wang Hongwen, Deng Xiaoping, Hua Guofeng, or other successors, Mao's intentions fell under the scope of Party-based succession. Lin Biao's succession was written into the Party constitution approved during the Ninth Party Congress. Five years passed from the time of Lin Biao's death in the September 13 Incident until Mao's death. In accordance with Mao's wishes, the CCP Central Committee's daily operations were managed by four different people in succession: Zhou Enlai, Wang Hongwen, Deng Xiaoping, and Hua Guofeng. Others Mao may have considered as possible successors include Zhang Chunqiao, Ji Dengkui, and Li Desheng.

Official propaganda typically highlights the legitimacy of whoever is in power. When Hua Guofeng took power, the propaganda emphasised Mao's trust in Hua. When Deng Xiaoping took power, the emphasis was on Mao's appreciation of Deng. Independent historians are able to see beyond the official propaganda. The book Unsustainable Sustained Revolution by Shi Yun and Li Danhui, (32) for example, considers the choice of successors in Mao's later years, with analysis of Zhou Enlai, Deng Xiaoping, Wang Hongwen, Zhang Chunqiao, Jiang Qing, and Hua Guofeng. The authors find that while Mao was dissatisfied with Zhou, he found him indispensible. When Zhou died before Mao, this succession option vanished. Wang Hongwen was a Liu Penzi type; (33) Mao at one point held out some hope for him and gave him a try, but when Wang proved unequal to the task, Mao gave up on him. Mao had no doubts of Deng Xiaoping's abilities, and put him in charge for a period of time in 1975. Mao perceived, however, that Deng intended to negate the Cultural Revolution. Mao considered the Cultural Revolution one of the two great accomplishments of his life; to negate the Cultural Revolution would be to negate half of himself. He therefore launched the campaign to criticise Deng and beat back the Right-deviationist Wind of Reversing Verdicts, causing Deng to fall from power once again.

Shi Yun and Li Danhui write, "From the perspective of consolidating the Cultural Revolution, Mao's most appropriate successor was Zhang Chunqiao." (34) Gao Wenqian says that Zhang Chunqiao "was a true disciple of the ideology of Mao's later years." (35) Zhang was in fact the faithful torch-bearer of Mao's ideology of sustained revolution under the dictatorship of the proletariat. However, Lin Biao and then Kang Sheng raised objections to Zhang Chunqiao, and during the second plenum of the Ninth Central Committee, numerous members and alternate members of the Central Committee expressed their dislike of Zhang, leaving Mao with no alternative but to abandon his plans to pass supreme power to him. After Zhou Enlai died in January 1976, Mao had Mao Yuanxin pass on the message, "Tell Wang Hongwen and Zhang Chunqiu to hold back." He proposed Hua Guofeng to serve as Premier and convenor of the Central Committee Politburo. Although Mao in his declining years was obliged to assign management of the Central Committee's day-to-day operations to someone who was acceptable to everyone and who was also a beneficiary of the Cultural Revolution, when he in April 1976 took the next step of appointing Hua first vice-chairman of the Central Committee and State Council Premier, it could hardly be said that he had no intention of passing his authority to Hua. Therefore, the result of Mao's actual political actions undeniably qualifies as Party-based succession.

There are many other Mao-related topics presenting considerable scholarly leeway for empirical research. Nanjing University professor Gao Hua can be considered a pioneer in this area. His book How the Red Sun Rose ${ }^{(36)}$ received a positive reception in academic circles for its combing of sound historical data. Gao's unfortunate passing last year raised expressions of grief and tribute from all quarters. This shows a genuine demand among readers for serious and solid empirical research. I will continue my own efforts in this area.

\section{Translated from Chinese by Stacy Mosher}

I Ding Dong, a scholar, was born in 1951 and now lives in Beijing. He is the author of Long Musings on a Winter's Night (Dong ye chang kao), Conversations with Friends (He youren duihua), Priceless Honour (Zunyan wujia), Browsing at Midnight (Wuye fanshu), Mental Exercise (Sixiang caolian), Spiritual Wanderings (Jingshen liulang), A Record of Education Speeches (Jiaoyu fangyan lu), and Cultural Decameron (Wenhua shiritan), and is currently focusing his research on the history and culture of modern China.

31. Jianguo yilai Mao Zedong wengao (Manuscripts of Mao Zedong since the founding of the PRC), vol. 13, p. 4, Zhongyang wenxian chubanshe, 1988.

32. Shi Yun and Li Danhui, Nanyi jixu de "jixu geming" (The unsustainable "sustained revolution"), Hong Kong, The Chinese University Press, 2008.

33. TN: Liu Penzi was a puppet emperor who ascended the Han dynasty throne in 25 AD, when he was just 15. His essentially powerless reign lasted only two years.

34. Shi Yun and Li Danhui, op. cit., p. 184.

35. Gao Wenqian, Wannian Zhou Enlai (Zhou Enlai's later years), Hong Kong, Mirror Publishing, 2003, p. 550.

36. Gao Hua, Hong taiyang shi wenyang shengqi de (How the red sun rose), Hong Kong, The Chinese University Press, 2000. 